\title{
XLV. On the specific gravity of certain substances in the solid state and in aqueous solution
}

\section{J.A. Groshans}

To cite this article: J.A. Groshans (1884) XLV. On the specific gravity of certain substances in the solid state and in aqueous solution, Philosophical Magazine Series 5, 18:114, 405-416, DOI: 10.1080/14786448408627614

To link to this article: http://dx.doi.org/10.1080/14786448408627614

Published online: 29 Apr 2009.

Submit your article to this journal $₫$

ЏII Article views: 2

Q View related articles $\square$ 


\section{[ 405$]$}

XLV. On the Specific Gravity of certain Substances in the Solid State and in Aqueous Solution. By J.A. Groshans*.

CSEFUL compilations, like those of Landolt and Börnsteint, render easy the observation of certain physical properties characterizing whole classes of bodies. We have been studying the specific gravities of some solid substances, and we will proceed directly to the discussion of one or two particular cases.

Analogous Compounds of Potassium and Sodium.

The atomic weight of sodium is 23 and its specific gravity 0.97 ; the atomic weight of potassium is 39 and its specific gravity 0.87 : sodium is the heavier of the two.

We find an apparent anomaly in all the compounds of these two bodies : in the solid state the sodium compound possesses a greater specific weight than that of the analogous compound of potassium, the two specific gravities bearing to one another the mean ratio of about $1 \cdot 10$ to 1 . But for aqueous solutions, with an equal number of molecules of water (for example 100 and 200), the reverse is true ; for then the density of the solution which contains the potassium is always greater than the one containing the sodium. Table $A$ shows the first case.

Table A.

The Specific Gravities, at the ordinary temperature, of the analogous compounds of Potassium and Sodium.

\begin{tabular}{|c|c|c|c|c|c|}
\hline Example. & $\begin{array}{l}\text { Potassium } \\
\text { compound. }\end{array}$ & $\begin{array}{l}\text { Specific } \\
\text { gravity. }\end{array}$ & $\begin{array}{l}\text { Sodium } \\
\text { compound. }\end{array}$ & $\begin{array}{l}\text { Specific } \\
\text { gravity. }\end{array}$ & $\begin{array}{l}\text { Ratio of } \\
\text { specific } \\
\text { gravities. }\end{array}$ \\
\hline $\begin{array}{ll}1 & \ldots \ldots \\
2 & \ldots \ldots \\
3 & \ldots \ldots \\
4 & \ldots \ldots \\
5 & \ldots \ldots\end{array}$ & $\begin{array}{l}\mathrm{K} \mathrm{Cl} \\
\mathrm{KBr} \\
\mathrm{KI} \\
\mathrm{KF} \\
\mathrm{KNO}_{3}\end{array}$ & $\begin{array}{l}1 \cdot 977 \\
2 \cdot 690 \\
3 \cdot 070 \\
2 \cdot 481 \\
2 \cdot 092\end{array}$ & $\begin{array}{l}\mathrm{NaCl} \\
\mathrm{NaBr} \\
\mathrm{NaI} \\
\mathrm{NaF} \\
\mathrm{NaNO}_{3}\end{array}$ & $\begin{array}{l}2 \cdot 150 \\
3 \cdot 014 \\
3 \cdot 550 \\
2 \cdot 766 \\
2 \cdot 130\end{array}$ & $\begin{array}{l}1 \cdot 087 \\
1 \cdot 120 \\
1 \cdot 165 \\
1 \cdot 115 \\
1 \cdot 197\end{array}$ \\
\hline $\begin{aligned} 6 & \ldots \ldots . \\
7 & \ldots \ldots \\
8 & \ldots \ldots \\
9 & \ldots \ldots \\
10 & \ldots \ldots .\end{aligned}$ & $\begin{array}{l}\mathrm{KClO}_{3} \\
\mathrm{KBrO}_{3} \\
\mathrm{KTO}_{3} \\
\mathrm{KPO}_{3} \\
\mathrm{KOH}\end{array}$ & $\begin{array}{l}2 \cdot 331 \\
3 \cdot 240 \\
3 \cdot 890 \\
2 \cdot 258 \\
2 \cdot 044\end{array}$ & $\begin{array}{l}\mathrm{NaClO}_{3} \\
\mathrm{NaBrO}_{3} \\
\mathrm{NaIO}_{3} \\
\mathrm{NaPO}_{3} \\
\mathrm{NaOH}^{2}\end{array}$ & $\begin{array}{l}2 \cdot 289 \\
3 \cdot 339 \\
4 \cdot 277 \\
2 \cdot 476 \\
2 \cdot 130\end{array}$ & $\begin{array}{l}0.982 \\
1 \cdot 030 \\
1 \cdot 100 \\
1.211 \\
1.042\end{array}$ \\
\hline $\begin{array}{ll}11 & \ldots . . \\
12 & \ldots \ldots . \\
13 & \ldots \ldots .\end{array}$ & $\begin{array}{l}\mathrm{K}_{2} \mathrm{~S} \\
\mathrm{~K}_{2} \mathrm{CO}_{3} \\
\mathrm{~K}_{2} \mathrm{SO}_{4}\end{array}$ & $\begin{array}{l}2 \cdot 130 \\
2 \cdot 290 \\
2 \cdot 647\end{array}$ & $\begin{array}{l}\mathrm{Na}_{2} \mathrm{~S} \\
\mathrm{Na}_{2} \mathrm{OO}_{3} \\
\mathrm{Na}_{42} \mathrm{SO}_{4}\end{array}$ & $\begin{array}{l}2 \cdot 471 \\
2 \cdot 476 \\
2 \cdot 655\end{array}$ & $\begin{array}{l}1.079 \\
1.081 \\
1.003\end{array}$ \\
\hline \multicolumn{5}{|c|}{ Mean ratio .......... } & 1.095 \\
\hline
\end{tabular}

* Communicated by the Author, and translated from the French by Frederick H. Hatch.

† Physikalisch-chemische Tabellen (Berlin, 1883). 


\section{M. J. A. Groshans on the Specific Gravity of certain}

These data are taken from the tables of Landolt and Börnstein.

The second table, B, shows what we may call (in a certain sense) the opposite phenomenon. This table gives the densities of solutions containing one molecule of the soluble body with whole numbers (equal for the two bodies) of molecules of water; one sees clearly that the solutions which contain potassium are heavier than those containing sodium.

\section{TABLE B.}

Solutions of analogous compounds of Potassium and Sodium, containing one molecule of the soluble substance with $n$ molecules of water, $\mathrm{H}_{2} \mathrm{O}$.

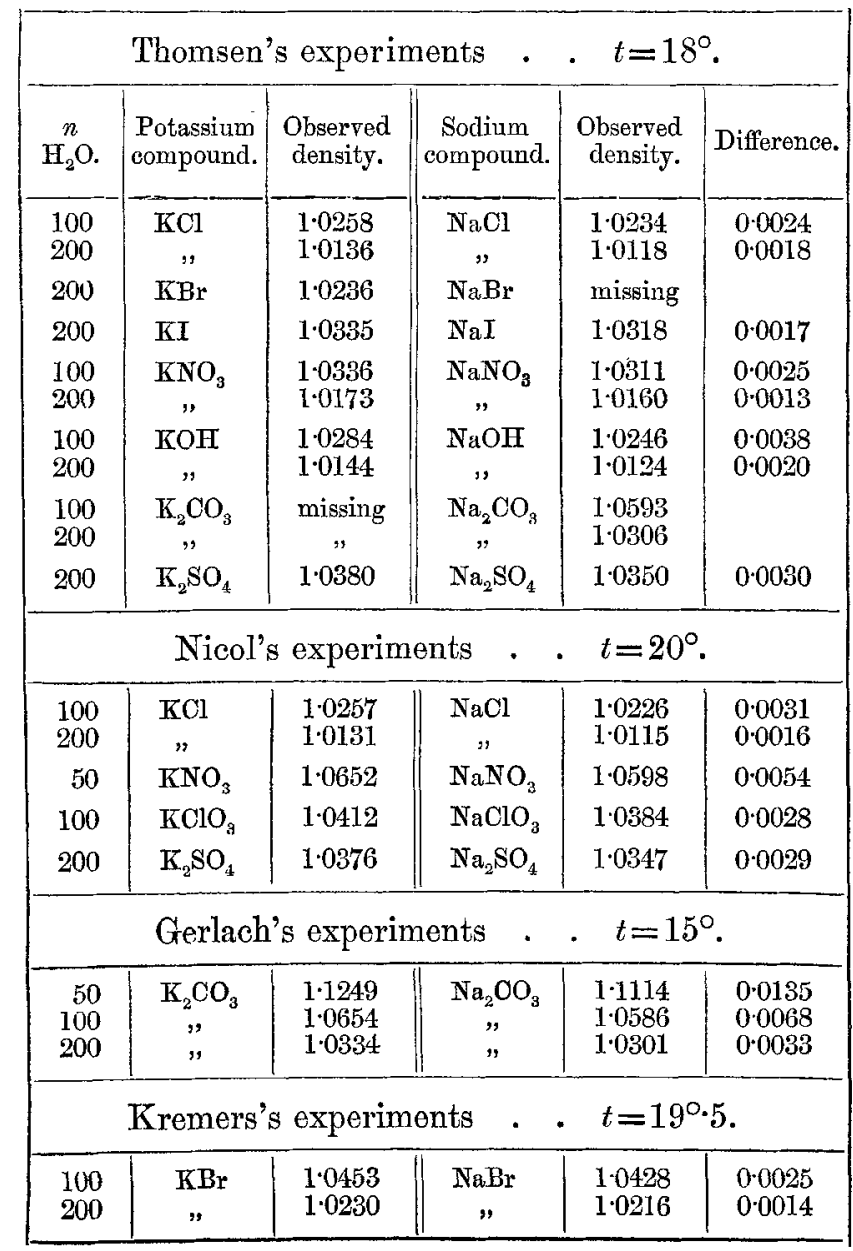


All the densities given in Table B are $d \frac{t^{\circ}}{t^{\circ}}$, and not $d_{4^{\circ}}^{t^{\circ}}$ Those given under the names of Gerlach and Kremers are not the direct results of observation, like those of Thomsen and Nicol. We have calculated them from other experiments of the two observers; and we shall return later on to this calculation. These densities have been added to the table to fill up gaps in Thomsen's experiments. We have nothing to add concerning the compounds of potassium and sodium; we therefore pass on to an analogous case.

\section{Analogous Compounds of Fluorine and Chlorine.}

It may have already been remarked, in Table $A$, how great the specific gravities of $\mathrm{KF}$ and $\mathrm{NaF}$ are, compared with the analogous compounds $\mathrm{KCl}$ and $\mathrm{NaCl}$. In reality this case bears a strong resemblance to the one we have just been examining. The compounds of fluorine, of which the molecular weights are smaller than those of the analogous compounds of chlorine, have greater specific gravities; the difference in the molecular weights $\mathrm{Cl}-\mathrm{F}$ is nearly equal to that between $\mathrm{K}-\mathrm{Na}$; being for $\mathrm{Cl}-\mathrm{F}=16.5$ for one molecule, 33 for two molecules, and 49.5 for three molecules. However, the specific gravities of the fluorine compounds are greater than those of the chlorine compounds; and the difference is about three times more than in our first case : this will be evident on referring to Table $\mathrm{C}$.

\section{TABLe $\mathrm{C}$.}

Specific Gravities, at the ordinary temperature, of the analogous compounds of Fluorine and Chlorine.

\begin{tabular}{|c|c|c|c|c|c|}
\hline Example. & $\begin{array}{l}\text { Fluorine } \\
\text { compound. }\end{array}$ & $\begin{array}{l}\text { Specific } \\
\text { gravity. }\end{array}$ & $\begin{array}{l}\text { Chlorine } \\
\text { compound }\end{array}$ & $\begin{array}{l}\text { Specific } \\
\text { gravity. }\end{array}$ & $\begin{array}{l}\text { Ratio of } \\
\text { specific } \\
\text { gravities. }\end{array}$ \\
\hline $\begin{array}{ll}1 & \ldots \ldots \\
2 & \ldots . . \\
3 & \ldots . . .\end{array}$ & $\begin{array}{l}\mathrm{XiF} \\
\mathrm{NaF} \\
\mathrm{Ka} F\end{array}$ & $\begin{array}{l}2 \cdot 60 \\
2 \cdot 77 \\
2 \cdot 48\end{array}$ & $\begin{array}{l}\mathrm{LiCl} \\
\mathrm{NaCl} \\
\mathrm{KOl}\end{array}$ & $\begin{array}{l}2.04 \\
2.15 \\
1.98\end{array}$ & $\begin{array}{l}1.275 \\
1.289 \\
1.253\end{array}$ \\
\hline 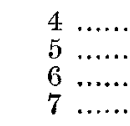 & $\begin{array}{l}\mathrm{MgF}_{2} \\
\mathrm{CaF}_{2} \\
\mathrm{BaF}_{2} \\
\mathrm{PbF}_{2}\end{array}$ & $\begin{array}{l}2 \cdot 47 \\
3 \cdot 18 \\
4 \cdot 83 \\
8 \cdot 24\end{array}$ & $\begin{array}{l}\mathrm{MgOl}_{2} \\
\mathrm{CaCl}_{2} \\
\mathrm{BaCl}_{2} \\
\mathrm{PbCl}_{2}\end{array}$ & $\begin{array}{l}2 \cdot 18 \\
2 \cdot 22 \\
3 \cdot 85 \\
5 \cdot 80\end{array}$ & $\begin{array}{l}1 \cdot 133 \\
1 \cdot 433 \\
1.254 \\
1.421\end{array}$ \\
\hline $8 \ldots \ldots$ & $\mathrm{AsF}_{3}$ & 267 & $\mathrm{AsCl}_{3}$ & $2 \cdot 20$ & 1.284 \\
\hline \multicolumn{5}{|c|}{ Mean 1} & $1 \cdot 293$ \\
\hline
\end{tabular}

The two compounds of arsenic, $\mathrm{AsF}_{3}$ and $\mathrm{AsCl}_{3}$, are, as we know, liquid at the ordinary temperature.

It may be asked, in what way does the phenomenon present itself in solutions; which of the two solutions has the greater 


\section{M. J. A. Groshans on the Specific Gravity of certain}

density, that with $\mathrm{F}$ or that with $\mathrm{Cl}$ ? For this we have not such a large number of examples as in the first case; we know that the greater part of the compounds of fluorine in Table $\mathrm{C}$ are insoluble.

We have come across Kohlrausch's researches on the fluoride of potassium, $\mathrm{KF}$; and we have calculated, in round numbers, from his experiments the densities for integral numbers of molecules of water. The results of these calculations are in Table D; and we have placed opposite to them the observed densities of the solutions of KCl of Thomsen, with the same number of molecules of water.

\section{TABLE D.}

Comparison of the Densities of Solutions of $\mathrm{KF}$ and $\mathrm{KCl}$ containing an equal number of molecules of water $(n)$.

\begin{tabular}{|c|c|c|c|}
\hline$n$. & $\begin{array}{c}\text { KF, } \\
\text { Kohlrausch, } \\
t=18^{\circ} . \\
\text { Calculated } \\
\text { density. }\end{array}$ & $\begin{array}{c}\text { KCl, } \\
\text { Thomsen, } \\
t=18^{\circ} . \\
\text { Observed } \\
\text { deneity. }\end{array}$ & Differences. \\
\hline 15 & 1.1560 & $1 \cdot 1468$ & 0.0092 \\
30 & 1.0832 & 1.0800 & 0.0032 \\
50 & 1.0515 & 1.0496 & 0.0019 \\
100 & 1.0263 & 1.0258 & 0.0005 \\
200 & 1.0133 & 1.0136 & 0.0003 \\
\hline
\end{tabular}

The densities here are $d \frac{t^{\circ}}{t^{\circ}}$.

We see in this table that the two solutions have equal densities when they are sufficiently dilute.

This example proves that the densities of solutions does not depend upon the greatness of the molecular weight of the dissolved substance; for the molecular weight of $\mathrm{KCl}$ is greater than that of $\mathrm{KF}$.

On the Method employed in calculating the Densities of a Solution, with arbitrary numbers of Molecules of Water, taking two experiments for the basis of the Calculation.

In explaining this method of calculation, it will be necessary for us to touch upon some of the results of our researches upon solution, which have been published elsewhere.

We may regard a solution as a compound of one part (a gramme) of the soluble substance with a variable number of grammes of water; this number we will call aq. We shall show that the density of a solution can be represented with a 
Substances in the Solid State and in Aqueous Solution. 409 considerable degree of accuracy by the formula

$$
d=1+\frac{\alpha}{a q+\beta}
$$

( $\alpha$ and $\beta$ are two constants given by two experiments).

Table $\mathrm{E}$ shows the agreement of the results obtained by the use of the interpolation-formula with the results of direct experiment. This table is copied from a publication of a research by Dr. G. Th. Gerlach*.

TABLE E.

Experiments of Gerlach on a Solution of Crystallized Citric Acid; $t=15^{\circ}$.

\begin{tabular}{|c|c|c|c|c|}
\hline $\begin{array}{c}\text { Weight } p \text { in } \\
100 \text { parts } \\
\text { of the } \\
\text { dissolved } \\
\text { body. }\end{array}$ & $\begin{array}{c}\mathrm{Aq} . \\
100-p\end{array}$ & $\begin{array}{c}d \frac{15^{\circ}}{15^{\circ}} \\
\text { (observed). }\end{array}$ & $\begin{array}{c}\text { Difference } \\
\text { Density } \\
\text { (calculated). } \\
\text { calculated } \\
\text { and } \\
\text { observed } \\
\text { result. }\end{array}$ \\
\hline 10 & 9 & 1.03916 & & \\
20 & 4 & 1.08052 & 1.080569 & 0.00005 \\
30 & $2 \frac{1}{3}$ & $1 \cdot 12439$ & $1 \cdot 124467$ & 0.00008 \\
40 & 1.5 & 1.17093 & $1 \cdot 170950$ & 0.00003 \\
50 & 1 & 1.22041 & & \\
\hline
\end{tabular}

We see that the results obtained by use of the interpolationformula leave nothing to be desired." The three results of the formula in the table have been calculated from two experiments, the first and the fifth, which give:-

$$
\begin{aligned}
\alpha & =0.380966 \quad \log \alpha=9.5807654 \\
\beta & =0.72844 \\
\alpha+\beta & =1.10941
\end{aligned}
$$

The sum $(\alpha+\beta)$ has some importance. Suppose that a weighed quantity, say 10 grammes, of pure water, of which the volume at $4^{\circ}=10$ cubic centimetres and at $t^{\circ}$ a little more, is added to a concentrated solution. Theoretically three cases can occur:-

1. The increase of rolume of the solution can be exactly equal to the added volume of the pure water: in this case we should have $(\alpha+\beta)=1$.

2. The increase of volume can be less than the added water; this is the ordinary case. It is then said that the solution is accompanied by "contraction;" in this case we find $(\alpha+\beta)$ greater than 1 ; in general the sum $(\alpha+\beta)$ is between 1 and 2 .

3 . In the third case the volume of the solution is increased

- Specifische Gewichte der gebräuchlichsten Salzlösungen (Freiberg, 1859). Phil. Mag. S. 5. Vol. 18. No. 114. Nov.1884. $2 \mathrm{E}$ 


\section{M. J. A. Groshans on the Specific Gravity of certain}

by a greater quantity than the water which has been added; $(\alpha+\beta)$ would be less than unity.

Space does not allow of our saying more about the sum $(\alpha+\beta)$.

Instead of considering solution as a combination of one gramme of the soluble body with aq grammes of water, one often prefers to consider it as a diffusion of a molecule part of the soluble substance, or $a$ grammes ( $a$ being the molecular weight of the substance in solution) through $n$ molecules of water ; instead of $n$ wo will employ the letter A. In this case we can make use of the same interpolation-formula, after having modified it in the following manner:-

Since $A=a / 18$ aq., we multiply both terms $a$ and $\beta$ by $a / 18$; the fraction remains unchanged; and the new interpolation-formula becomes

$$
d=1+\frac{\nu}{\mathrm{A}+\lambda} ;
$$

in which $\nu=a / 18 \alpha$, and $\lambda=a / 18 \beta$.

$$
(\nu+\lambda) 18 / \alpha=\alpha+\beta .
$$

With this formula we have calculated the density of the solution of sugar, $\mathrm{C}_{12} \mathrm{H}_{22} \mathrm{O}_{11}, a=342$, according to the experiments of Gerlach. For the integral values (in round numbers) of A, we have taken, as the basis of our calculations, the two following experiments of Gerlach :-

\section{Percentage $p$ of sugar.}<smiles></smiles>

$40 \quad \ldots . . \quad 1 \cdot 5$

From which we have

$$
\begin{aligned}
\nu & =7 \cdot 3526 \\
\lambda & =12 \cdot 494 \\
\nu+\lambda & =19 \cdot 8466 \\
\text { TABLE } & \text { F. }
\end{aligned}
$$

A。 $28 \cdot 5$

\begin{tabular}{|c|c|c|c|}
\hline $\begin{array}{c}\text { Molecules of } \\
\mathrm{H}_{2} \mathrm{O} \text {. } \\
\text { A. }\end{array}$ & $\begin{array}{l}\text { Gerlach, } \\
\text { calculated } \\
\text { density. } \\
d \frac{17^{\circ \cdot 5}}{17^{\circ} \cdot 5} .\end{array}$ & $\begin{array}{c}\text { Marignac, } \\
\text { observed } \\
\text { density. } \\
d \frac{20^{\circ}}{20^{\circ}}\end{array}$ & $\begin{array}{c}\text { Difference. } \\
\mathbf{G}-\mathbf{M}\end{array}$ \\
\hline 25 & $1 \cdot 19610$ & $1 \cdot 19448$ & +0.00162 \\
\hline 50 & $1 \cdot 11765$ & $1 \cdot 11699$ & 0.00066 \\
\hline 100 & $1 \cdot 06536$ & 1.06517 & 0.00019 \\
\hline 200 & 1.03460 & $1 \cdot 03444$ & 0.00016 \\
\hline 400 & 1.01782 & 1.01770 & 0.00012 \\
\hline
\end{tabular}
$17^{\circ} \cdot 5 / 17^{\circ} \cdot 5$ $1 \cdot 019686$ $1 \cdot 179358$

Solution of Sugar; Gerlach's experiments at $17^{\mathrm{c}} \cdot 5$, and Marignac's at $20^{\circ}$. 
Substances in the Solid State and in Aqueous Solution. 411

Table $\mathbf{F}$ contains the results of our calculations. We have chosen the same numbers for A that Marignac employed in his experiments upon the solution of sugar: and we have placed in the table the direct results of his observations, for the purpose of comparison. We see that the results of the two investigators, Gerlach and Marignac, very nearly agree. Gerlach's figures are a little high; but this little difference may be attributed to the difference of temperatures $t^{\circ}$, which were $17^{\circ} .5 \mathrm{C}$. for Gerlach and $20^{\circ} \mathrm{C}$. for Marignac. We have still to multiply all the densities observed by Marignac by the number 1.001731 , because he has expressed them with water at $4^{\circ} \mathrm{C}$. taken as unity; his densities $d \frac{20^{\circ}}{4}$ have then been converted into $d \frac{20^{\circ}}{20^{\circ}}$, to render them, as nearly as possible, comparable with Gerlach's densities, $17^{\circ} \cdot 51 / 17^{\circ} \cdot 5$.

The two interpolation-formulæ are not applicable to the densities $d \frac{t^{\circ}}{4^{\circ}}$. See Table G. In this table we have applied our formula to two of Marignac's series of densities, the densities $20^{\circ} / 4^{\circ}$ and the densities $20^{\circ} / 20^{\circ}$.

\section{TABLE G.}

Marignac's experiments on Solutions of Sugar. Application of the Interpolation-formulæ to $d 20^{\circ} / 4^{\circ}$ and to $d 20^{\circ} / 20^{\circ}$.

\begin{tabular}{|c|c|c|c|}
\hline A. & $\begin{array}{l}d 20^{\circ} / 4^{\circ} \\
\text { (observed). }\end{array}$ & $\begin{array}{l}\text { Density } \\
\text { calculated } \\
\text { by the } \\
\text { formula. }\end{array}$ & $\begin{array}{c}\text { Difference } \\
\text { between } \\
\text { observed and } \\
\text { calculated } \\
\text { density. }\end{array}$ \\
\hline 25 & $1 \cdot 19242$ & & \\
\hline 50 & $1 \cdot 11506$ & $1 \cdot 11071$ & 0.00435 \\
\hline 100 & $1 \cdot 06333$ & $1 \cdot 05986$ & 0.00347 \\
\hline 200 & 1.03265 & 1.03120 & 0.00145 \\
\hline 400 & 1.01594 & & \\
\hline A. & $\begin{array}{c}d \frac{20^{\circ}}{4^{\circ}}, \\
\text { conrerted to } \\
d 20^{\circ} / 20^{\circ} .\end{array}$ & $\begin{array}{l}\text { Density } \\
\text { calculated } \\
\text { by the } \\
\text { formula. }\end{array}$ & $\begin{array}{l}\text { Difference } \\
\text { between } \\
\text { observed and } \\
\text { calculated } \\
\text { density. }\end{array}$ \\
\hline 25 & $1 \cdot 19448$ & & \\
\hline 50 & $1 \cdot 11699$ & $1 \cdot 11674$ & 0.00025 \\
\hline 100 & $1 \cdot 06517$ & 1.06488 & 0.00029 \\
\hline 200 & 1.08444 & 1.03435 & 0.00008 \\
\hline 400 & 1.01770 & & \\
\hline
\end{tabular}

$2 \mathrm{E} 2$ 


\section{M. J. A. Groshans on the Specific Gravity of certain}

For $d 20^{\circ} / 4^{\circ}$ and $a 20^{\circ} / 20^{\circ}$ the densities (in Table G) have been calculated three times from the first and fifth experiments.

Using the densities $20^{\circ} / 20^{\circ}$, we have

$$
\begin{array}{rlrl}
\nu & =7 \cdot 30208 & \log \nu & =0.8634464, \\
\lambda & =12.5467 & \\
\text { Sum ... } & 19.8487 & \alpha+\beta & =1.0447 .
\end{array}
$$

These figures are almost the same as those which were obtained from Gerlach's two experiments.

Table $G$ shows that the interpolation-formula represents, within a near approximation, the densities $20^{\circ} / 20^{\circ}$ - that is to say, the densities $t^{\circ} / t^{\circ}$; but not so well the densities $20^{\circ} / 4^{\circ}$, or $d t^{\circ} / 4^{\circ}$.

It would seem as if the density $t^{\circ} / t^{\circ}$ were the expression most suited to the nature of solution; the conversion of $d t^{\circ} / t^{\circ}$ into $d t^{\circ} / 4^{\circ}$ might resemble somewhat an arbitrary change, altering the nature of the results. At the same time, the densities $t^{\circ} / t^{\circ}$ have the advantage of making it easier to compare the results of different observers. This would still more be possible if all investigators were to make use of the same fixed temperature $t^{\circ}$ when the so-called ordinary temperature is in question.

We could also wish that it were always clearly stated if the temperature in question be $t^{\circ} / t^{\circ}$ or $t^{\circ} / 4^{\circ}$; one is often in doubt about this important point, especially when obliged to cite from second-hand sources. But we must proceed.

We have shown the method we have employed in Kohlrausch's experiments on the solution of $\mathrm{KF}$, which are described in the important work of G. Wiedemann on Electricity, vol. i. p. 593. In all, we have chosen three experiments.

Kohlrausch's experiments on a solution of KF.

$\begin{array}{ccccc}p . \quad \text { aq. } & \text { A. } & d 18^{\circ} / 18^{\circ} . & d 18^{\circ} / 4^{\circ} \text { ? } \\ 5 \ldots . . .19 & 61 \frac{2}{9} & 1.0424 & 1 \cdot 041 \\ 10 \ldots . . . & 9 & 29 & 1.0854 & 1.084 \\ 40 \ldots . . . & 1.5 & 4.833 & 1.3798 & 1.378\end{array}$

We have commenced by changing the given densities (those with three decimals), which we suppose to be $18^{\circ} / 4^{\circ}$, into $18^{\circ} / 18^{\circ}$. We have then calculated the two constants, taking the mean of the first and third experiments; and have thus obtained the following mean result:-

$$
\begin{aligned}
\nu=2 \cdot 69133 & \log \nu=0 \cdot 4299663 \\
\lambda=2 \cdot 25270 & \\
\operatorname{Sum~} \ldots \overline{4 \cdot 94403} & \alpha+\beta=1 \cdot 5343
\end{aligned}
$$


Substances in the Solid State and in Aqueons Solution. 413

Applying the formula thus obtained to the second experiment, we have :-

$$
\begin{aligned}
& d 18^{\circ} / 18^{\circ} \text { (observed) }=1.0854 \\
& d 18^{\circ} / 18^{\circ} \text { (calculated) }=1.0861
\end{aligned}
$$

If a similar calculation be made for $\mathrm{KCl}$ from Thomsen's two experiments (given in Table D) corresponding with $A=15$ and 100 , the following results are obtained :-

$$
\begin{aligned}
\nu=2 \cdot 6606 & \log \nu=0.4249793 \\
\lambda=3.1240 & \\
\text { Sum ... } 5 \cdot 7846 & \alpha+\beta=1.397
\end{aligned}
$$

We see that the two solutions (that of $\mathrm{KF}$ and that of $\mathrm{KCl}$ ) have almost the same $v$; but the two $\lambda$ 's are a little different:

$$
\begin{aligned}
\text { For } \mathrm{KCl}, \lambda & =3 \cdot 124 \\
\text { ", } \mathrm{KF}, \lambda & =2 \cdot 253 \\
\text { Difference } & =\overline{0.871}
\end{aligned}
$$

This difference, which is somewhat large, varies with the different densities of the two substances in the solid and anhydrous state (see Table C).

We may here mention a special property of our interpolationformula.

If aq or $\mathrm{A}$ be made $=0$, the formulæe become

$$
d=1+\frac{\alpha}{\beta}=1+\frac{\nu}{\lambda}=\delta ;
$$

and they then express the specific gravity of the dissolved substance in the anhydrous state; we call this particular value of $d, \delta$.

The value of $\delta$, calculated by the formula, in some cases approaches very nearly to that of direct observation. For example, Marignac gives somewhere the specific gravity of crystallized sugar as 1.59 .

Now our calculations (from $d 20^{\circ} / 20^{\circ}$ ) give

$$
\delta=1+\frac{\nu}{\lambda}=1.582 \text {. }
$$

Since, according to Table $\mathrm{C}$, the specific weights $\delta$, observed for $\mathrm{KF}$ and $\mathrm{KCl}$, are respectively $2 \cdot 48$ and 1.98 , and thus far from equal, it follows that in the two substances we may have $y=\nu^{\prime}$ (nearly), but not $\lambda=\lambda^{\prime}$; for (assuming our interpolationformula and the results of observation to be perfectly accurate) we should have for

$$
\begin{array}{cc}
\text { KF. } & \text { KCl. } \\
\delta=1+\frac{\nu}{\lambda}=2 \cdot 48 ; & \delta^{\prime}=1+\frac{\nu^{\prime}}{\lambda^{\prime}}=1 \cdot 98 .
\end{array}
$$




\section{M. J. A. Groshans on the Specific Gravity of certain}

Whereas, starting from the values of $\nu$ and $\lambda$, which have been obtained by calculation (by means of two experiments for each substance), we have :-

$$
\text { For } \mathrm{KF}, \delta=2 \cdot 19 ; \text { for } \mathrm{KCl}, \delta=1 \cdot 85 \text {. }
$$

These figures do not agree so well as those for the sugar ; but the agreement appears to us sufficient.

We see, in using this form of the interpolation-formula

$$
d=1+\frac{v}{\mathrm{~A}+\lambda},
$$

that when two different substances have the same $\nu$ (which often occurs), but slightly different values of $\lambda$, the densities of the two solutions can differ slightly for small values of $A$; but that the difference diminishes for greater values of $A$, and that the two densities become equal when $A=\infty$. This result for KF and KCl may be seen in Table D.

There are some substances which not only have the same $\nu$ but also the same $\lambda$, which occurs $\left(\nu, \nu^{\prime}\right.$ being assumed equal) when two similar substances, have the same specific gravity in the anhydrous state. We will give a single example of this.

On referring to Landolt's tables, we find for the two following substances:-

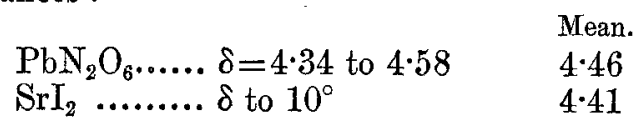

We have calculated $\nu$ and $\lambda$ for these substances according

\begin{tabular}{|c|c|c|c|c|c|}
\hline $\begin{array}{r}p \cdot \\
27 \cdot 5 \\
127 \cdot 9\end{array}$ & $\begin{array}{c}\mathrm{SrI}_{2} . \\
\text { Water. } \\
100 \\
100\end{array}$ & $\begin{array}{c}d 19^{\circ} 5 / 19^{\circ} 5 . \\
1.2160 \\
1 \cdot 8349\end{array}$ & $\begin{array}{c}p . \\
11 \cdot 10 \\
59 \cdot 02\end{array}$ & $\begin{array}{c}\mathrm{PbN}_{2} \mathrm{C} \\
\text { Water. } \\
100 \\
100\end{array}$ & $\begin{array}{c}d 6^{\circ} \cdot 5 / 19^{\circ} \cdot 5 \\
1.0931 \\
1.4496\end{array}$ \\
\hline \multicolumn{3}{|c|}{$\begin{array}{l}\nu=15 \cdot 7803 \\
\lambda=4 \cdot 0673\end{array}$} & \multicolumn{3}{|c|}{$\begin{array}{l}\nu=15 \cdot 793 \\
\lambda=3 \cdot 970\end{array}$} \\
\hline \multicolumn{3}{|c|}{ Sum ... $19 \cdot 8476$} & \multicolumn{3}{|c|}{ Sum $\ldots .19 \cdot 763$} \\
\hline \multicolumn{3}{|c|}{$\begin{array}{l}\alpha+\beta=1 \cdot 046, \\
\delta \text { calc. }=4 \cdot 88\end{array}$} & \multicolumn{3}{|c|}{$\begin{array}{l}\alpha+\beta=1 \cdot 0747 \\
\delta \text { calc. }=4.98\end{array}$} \\
\hline
\end{tabular}
to the following experiments of Kremers :-

Kremers's experiments.

Similar solutions of the two substances with an equal number, 
Substances in the Solid State and in Aqueous Solution. 415

A, of molecules of water have necessarily equal densities. We shall be pardoned the following calculations :-

Densities $19^{\circ} \cdot 5 / 19^{\circ} .5$, calculated from Kremers's experiments.

$\begin{array}{rrr}\text { A. } & \mathrm{SrI}_{2} & \mathrm{PbN}_{2} \mathrm{O}_{6} . \\ 50 & 1.2919 & 1 \cdot 2926 \\ 100 & 1.1516 & 1 \cdot 1519 \\ 200 . & 1 \cdot 0773 & 1.0774 \\ 300 & 1 \cdot 0391 & 1.0391\end{array}$

Among Thomsen's experiments the following is to be found:-

$$
\mathrm{PbN}_{2} \mathrm{O}_{6}+200 \mathrm{H}_{2} \mathrm{O}, d 18^{\circ} / 18^{\circ}=1 \cdot 0771 \text {. }
$$

Conclusion.

It is possible to form groups of substances of which the densities are equal when $\mathrm{A}=\mathrm{A}^{\prime}$. For instance, this is the case for the homonymous salts of $\mathrm{Fe}, \mathrm{Mn}$, and $\mathrm{Cr}$. We call the following salts homonymous:-

$\mathrm{RSO}_{4} ; \quad \mathrm{RCl}_{2} ; \mathrm{RN}_{2} \mathrm{O}_{6} ; \& \mathrm{c}$.

The same holds good for the homonymous salts of $\mathrm{Cu}, \mathrm{Zn}$, $\mathrm{Ni}$, and Co.

The following Table $\mathrm{H}$ contains several experiments (which have already been published) referring to this last case.

TABLE H.

Solutions with Equal Densities.

\begin{tabular}{|c|c|c|c|}
\hline \multicolumn{2}{|c|}{ Thomsen's experiments. $t=18^{\circ}}$. \\
\hline A. & $\begin{array}{c}\text { Dissolved } \\
\text { substance. }\end{array}$ & $d t^{\circ} t^{\circ}$. & Mean. \\
\hline 200 & $\mathrm{ZnSO}_{4}$ & 1.0455 & 1.0449 \\
200 & CuSO $_{4}$ & 1.0444 & \\
\hline \multicolumn{4}{|c|}{ Nicol's experiments. } \\
\hline 207 & $\mathrm{ZnSO}_{4}$ & 1.04367 & \\
207 & CuSO $_{4}$ & 1.04268 & 1.04308 \\
207 & COSO $_{4}$ & 1.04304 & 1.043 \\
207 & NisO $_{4}$ & 1.04296 & \\
\hline
\end{tabular}

For two substances which possess the same $v$ the values of $\alpha, \alpha^{\prime}$ are inversely proportional to the molecular weights $a, a^{\prime}$. 
It is often possible to foretell the value of $v$ which a substance will have, by making use of certain observations on the properties of solutions. For instance, if two substances be taken, $\mathrm{RI}_{2}$ and $\mathrm{RBr}_{2}, \mathrm{R}$ being the same for both, it will be found for the two substances,

$$
\nu-v^{\prime}=\text { constant. }
$$

We may express this result in a more general manner, thus:-

$$
\mathrm{I}-\mathrm{Br}=\text { constant. }
$$

In the same way,

$$
\mathrm{Br}-\mathrm{Cl}=\text { constant. }
$$

And, further, these two constants are equal to one another; so that we have

$$
\mathrm{I}-\mathrm{Br}=\mathrm{Br}-\mathrm{Cl}=\text { constant. }
$$

When two substances, such as $\mathrm{RI}_{2}$ and $\mathrm{R}^{\prime} \mathrm{I}_{2}$, have $\mathrm{R}, \mathrm{R}^{\prime}$ different, e. g. $\mathrm{Zn}$ and $\mathrm{Mg}$, we find in all cases, such as $\mathrm{ZnI}_{2}$ and $\mathrm{Mg} \mathrm{I}_{2}$, or $\mathrm{ZnSO}_{4}$ and $\mathrm{MgSO}_{4}$, \&c.,

$$
\mathrm{Zn}-\mathrm{Mg}=\text { constant. }
$$

The netals $\mathrm{Ca}, \mathrm{Sr}, \mathrm{Ba}$ give (like $\mathrm{Cl}, \mathrm{Br}, \mathrm{I}$ ):-

$$
\mathrm{Ba}-\mathrm{Sr}=\mathrm{Sr}-\mathrm{Ca}=\text { constant. }
$$

Space does not permit of our continuing this subject, which we have treated elsewhere in several published papers.

Scheveningen, Holland, August 1884.

XLVI. An overlooked Discoverer in the Theory of Determinants. By Thomas Muir, M.A., LL.D., F.R.S.E.*

1. NOTWITHSTANDING the care which has been taken, 1 especially on the Continent, in investigating the history of the Theory of Determinants, and notwithstanding the fact that, practically, the history extends no further back than somewhere about 130 years, there seems to be at least one investigator of considerable importance who has been altogether lost sight of. This is Ferdinand Sctwweins, born at Fürstenberg, Paderborn, in 1780, Professor in Heidelberg from 1811, died in 1856. Some time ago I came into possession of his Theorie der Differenzen und Differentiale, a handsome quarto volume of vi +666 pages, published in 1825 . On reading the title-page, which enumerates six other subjects besides Differences and Differentials, I found the names of two

* Communicated by the Author. 